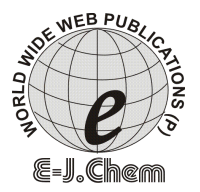

http://www.e-journals.net

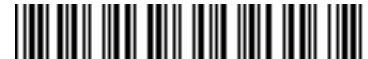

ISSN: 0973-4945; CODEN ECJHAO

E-Journal of Chemistry

Vol. 3, No.3, pp 146-153, July 2006

\title{
Rapid Spectrophotometric Determination of Trace Amounts of Nitrate-Nitrogen using Dapsone and $\alpha$-Naphthol
}

\author{
PADMARAJAIAH NAGARAJA, ${ }^{+}{ }^{\dagger}$ JAINARA S. PRAKASH*, \\ BESAGARAHALLY L. BHASKARA*, \\ Department of Studies in Chemistry, \\ University of Mysore, \\ Manasagangotri, Mysore - 570 006, India.
}

Received 10 May 2006; Accepted 2 June 2006.

\begin{abstract}
A simple, rapid and sensitive spectrophotometric method has been developed for the trace determination of nitrite using Dapsone and $\alpha$-Naphthol. The proposed method is based on the diazotization of Dapsone followed by coupling with $\alpha$-Naphthol in sodium hydroxide medium to give an intense pink coloured azo dye. The dye shows absorption maximum at $540 \mathrm{~nm}$. The molar absorptivity and Sandell's sensitivity being $5.749 \times 10^{4} 1 \mathrm{~mol}^{-1} \mathrm{~cm}^{-1}$ and $0.24 \mathrm{ng}$ $\mathrm{cm}^{-3}$ respectively. Tolerance limit for interfering ions and complexing agents were reported. Other analytical parameters and applications of the method for analysis of tap water, lake water, and industrial effluents have been investigated.
\end{abstract}

Keywords: Spectrophotometry, nitrite-nitrogen, $\alpha$-naphthol, industrial effluent

\section{Introduction}

Inadequately treated effluents of various industries add the contamination of nitrite in water. The presence of nitrite in water is harmful as it causes methemoglobinemea and forms carcinogenic nitrosomine when present with secondary or tertiary amines ${ }^{1,2}$; it also affects the dissolved oxygen content of water. The maximum permissible limit as fixed by U.S. Health Association is $0.06 \mu \mathrm{g} \mathrm{cm}^{-3}$ in potable water ${ }^{3}$. Nitrite concentrations in fresh water are usually very low, $0.001 \mathrm{mg} \mathrm{L}^{-1}, \mathrm{NO}_{2}^{-}-\mathrm{N}$, and rarely higher ${ }^{4}$ than $1.0 \mathrm{mg} \mathrm{L}^{-1}$. In view of the ubiquitous presence of nitrite in the environment, a sensitive method for trace level determination of nitrite is desirable. 
Nitrite has been determined by chemiluminescence ${ }^{5}$, fluorometry ${ }^{6}$, polarography ${ }^{7}$, Raman spectroscopy ${ }^{8}$, and gas chromatography-mass spectrometry ${ }^{9}$. Although these methods are quite sensitive, they have several limitations. These methods are difficult, time consuming and requires fairly sophisticated equipments. Recently, many papers have been published on the determination of nitrite based on its catalytic effect on the oxidation of organic compounds by bromate $\mathrm{e}^{10-12}$ or hydrogenperoxide ${ }^{13}$.

These methods are highly sensitive, but suffer from careful control of the temperature and strong interference from sulphide, iodide, thiocyante, vanadium and iron salts. Although nitrite can be determined by the above mentioned methods, the classical methods are spectrophotometric methods. Most spectrophotometric methods for the determination of nitrite in natural water and waste water were based on the Griess-Ilosvey reaction ${ }^{14}$, which was modified several times. Many methods other than diazotization reaction were reported for the determination of nitrite ${ }^{15,16}$, they are prone to problems of sensitivity and lack of selectivity, mainly due to interference. The spectrophotometric determination of nitrite in various samples by diazotization-coupling techniques ${ }^{17-19}$ is a very important and common analysis.

\section{Experimental}

Instrument

“SYSTRONICS SPECTROPHOTOMETER 106" model was used for electronic spectral measurements with $10 \mathrm{~mm}$ matched quartz cells.

Reagents

All chemicals used were of analytical grade and double distilled water was used throughout the experiments. Standard nitrite stock solution $\left(1000 \mu \mathrm{g} \mathrm{ml}^{-1}\right)$ was prepared by dissolving $150 \mathrm{mg}$ of pre-dried sodium nitrite in de-aerated doubly distilled water and standardized ${ }^{20}$, a small amount of chloroform was added as a stabliser and a pellet of sodium hydroxide was added to prevent the liberation of nitrous oxide. The working standard was prepared by appropriate dilution of the stock with de-aerated, doubly distilled water. $0.1 \%(\mathrm{w} / \mathrm{v})$ dapsone was prepared in $5 \%$ ethanol, $0.5 \%(\mathrm{w} / \mathrm{v}) \alpha$-naphthol in $100 \mathrm{ml}$ of $1.0 \mathrm{~mol} \mathrm{dm}^{-3}$ sodium hydroxide. $2 \mathrm{~mol} \mathrm{dm}^{-3}$ hydrochloric acid was prepared in double distilled water. Solutions of foreign ions were prepared according to west $^{21}$.

Sample Preparation

A water sample taken for the determination of nitrite was collected in glass or polythene bottles. A $100 \mathrm{ml}$ of water sample was placed in a beaker and $3.0 \mathrm{ml}$ of $1.0 \%$ mercuric chloride solution was added and allowed to stand for $5 \mathrm{~min}$., the solution was filtered to remove any sulphide and iodides present. A known volume of the filtrate was analyzed by the recommended procedure.

\section{Determination of nitrite-nitrogen $\left(\mathrm{NO}_{2}^{-}\right)$}

An aliquot of a stock solution containing 1.25-20 $\mu \mathrm{g}$ of $\mathrm{NO}_{2}^{-}$was transferred into a series of $25 \mathrm{ml}$ calibrated flasks to which $1.0 \mathrm{ml}$ of $0.1 \%$ dapsone, $1.0 \mathrm{ml}$ of $2 \mathrm{~mol} \mathrm{dm}{ }^{-3}$ hydrochloric acid were added and the mixture was allowed to stand for $2 \mathrm{~min}$. for diazotization to be completed. Then $2.5 \mathrm{ml}$ of $0.5 \% \alpha$-naphthol in sodium hydroxide solution was added and diluted to the mark with water, mixed well. The absorbance of the solution was measured at $540 \mathrm{~nm}$ against the corresponding reagent blank. The calibration graph was constructed by plotting the absorbance against the amount of nitrite- nitrogen. 


\section{Results and Discussion}

This method involves the diazotization of two primary amino groups in dapsone in hydrochloric acid medium and each diazonium group would then react with a molecule of $\alpha$-naphthol in alkali by electrophilic substitution at 4-position to produce an intense pink azo dye. An investigation of the continuous variation method of diazotized dapsone and $\alpha$ naphthol showed that diazotized dapsone interacts with $\alpha$-naphthol in the ratio 1:2, similar results have been observed with mole ratio method. The reaction sequence based on the above result in shown in scheme 1. The pink coloured azo dye shows a maximum absorbance at $540 \mathrm{~nm}$. The reagent blank had negligible absorbance at this wavelength. The absorbance spectra of the coloured species are presented in Figure 1.

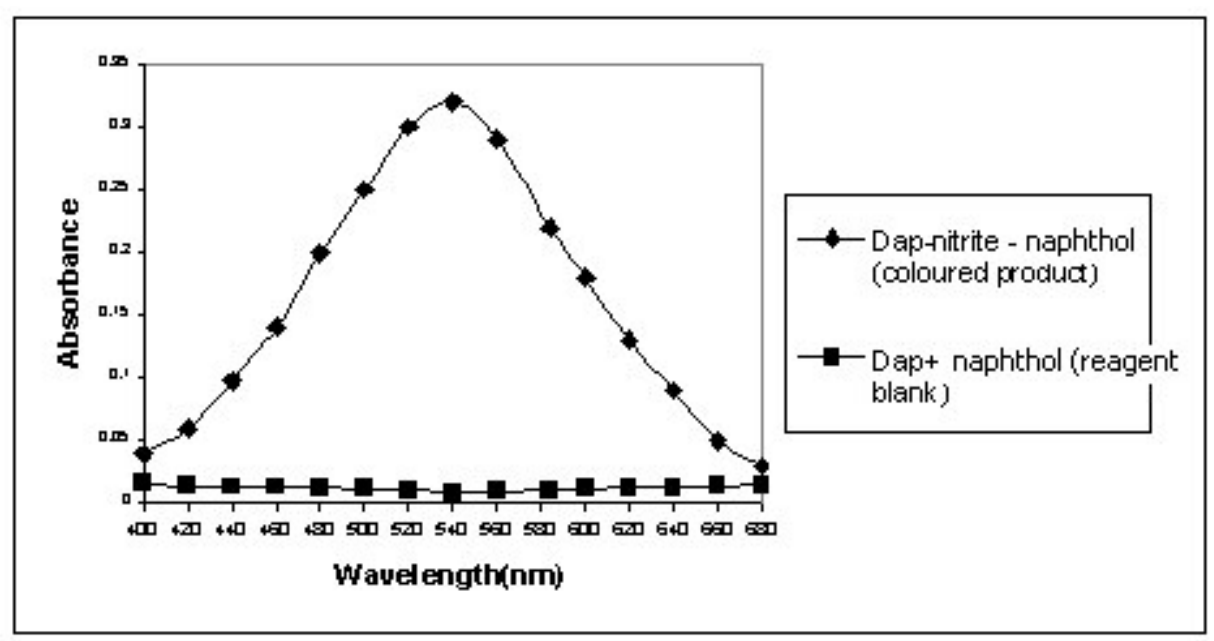

Figure 1 Absorption Spectra of the Reaction Product of Nitrite $\left(0.4 \mu \mathrm{G} \mathrm{Ml}^{-1}\right)$ and the Corresponding Reagent Blank

\section{Reactions Conditions}

Effect of acidity on diazotization

When no acid is present, diazotization does not take place. The effect of acidity on the diazotization was studied. The use of hydrochloric acid as the reaction medium was found to give the better results than use of sulphuric acid for diazotization. The hydrochloric acid concentration of at least $1.0 \mathrm{ml}$ of $2 \mathrm{~mol} \mathrm{dm}^{-3}$ was found necessary for complete diazotization. A $0.5-2.0 \mathrm{ml}$ of $2 \mathrm{~mol} \mathrm{dm}^{-3}$ hydrochloric acid range gave constant absorbance.

\section{Choice of Compound to be Diazotised and its Concentration Effect on Diazotsation.}

Many primary aromatic amines, including o-nitroaniline, p-aminosalicylic acid, p-aminobenzoic acid, and new sulfa compounds like sulfathiazole, sulfacetamide, sulfadiazine and dapsone were tested. Of these only dapsone gave satisfactory results. Moreover it is easily soluble in alcohol, giving colourless solution, is easily diazotized, and gives water soluble azo dye, under the conditions of the determination, thus eliminating the need for an extraction, a time consuming procedure. The effect of dapsone concentration was studied by using a fixed nitrite. It has been found that at least $0.8 \mathrm{ml}$ of $0.1 \%$ dapsone 
reagent is required to obtain maximum and constant absorbance. There is no appreciable change in the absorbance when the reagent concentration was varies in the range of 0.8-1.2 $\mathrm{ml}$ of $0.1 \%$ dapsone. Therefore $1.0 \mathrm{ml}$ of $0.1 \%$ dapsone was used for further studies.

Choice of coupling agent and its concentration effect with dapsone as a diazotising agent, various coupling agents like tiron, resorcinol, 8-hydroxy-quinoline, $\alpha$-naphthol and $\beta$-naphthol were tested for diazotization. $\alpha$-naphthol gave most useful results and was further studied. Using fixed nitrite and dapsone concentration on the colour intensity, 2.0$4.0 \mathrm{ml}$ of $0.5 \%$ alkaline $\alpha$-naphthol in $1.0 \mathrm{~mol} \mathrm{dm}^{-3}$ was sufficient for complete coupling the diazotized dapsone, and hence $2.5 \mathrm{ml}$ of $0.5 \%$ an alkaline $\alpha$-naphthol was used for further studies, a smaller volume decreased the absorbance.
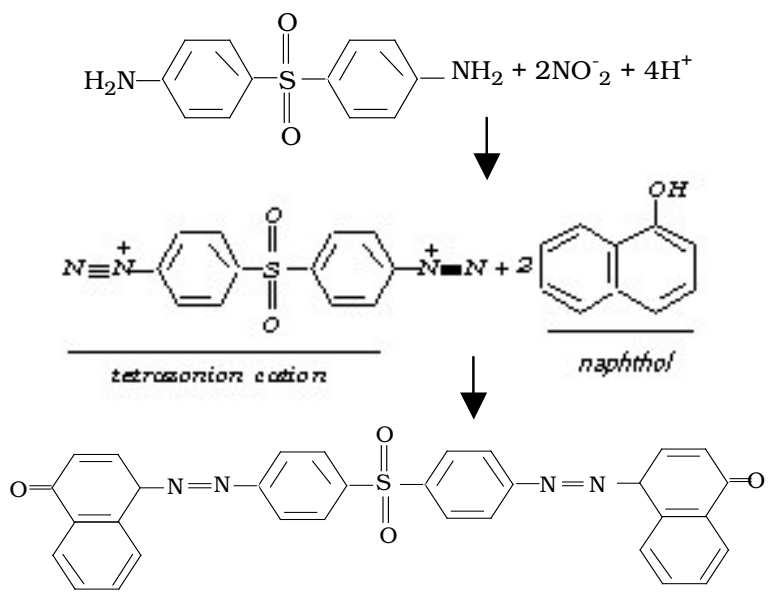

Scheme 1 Proposed Reaction Mechanism of the Formation of Coloured Product.

\section{Colour Stability}

Under the optimized conditions, although the pink colour develops instantaneously, $5 \mathrm{~min}$ is sufficient to obtain the maximum and constant absorbance. The dye showed no change in absorbance in $48 \mathrm{~h}$. The absorbance remained constant at $10-70^{\circ} \mathrm{C}$.

\section{Analytical Characteristics}

The colour system was found to obey Beer's law in the range of 1.25-20 $\mu \mathrm{g}$ of nitrite per 25 $\mathrm{ml}\left(0.05-0.8 \mu \mathrm{g} \mathrm{ml}^{-1}\right)$ of dapsone $-\mathrm{NO}_{2}^{-}-\alpha$-naphthol system. The molar absorptivity and Sandell's sensitivity were found to be $5.749 \times 10^{4} 1 \mathrm{~mol}^{-1} \mathrm{~cm}^{-1}$ and $0.243 \mathrm{ng} \mathrm{cm}^{-2}$ respectively with limit of detection $1.12 \mathrm{ng} \mathrm{cm}^{-3}$. The relative standard deviation was found to be 0.0017 for $0.4 \mu \mathrm{g} \mathrm{cm}^{-3}$ of $\mathrm{NO}_{2}^{-}$.

\section{Effect of Diverse Ions}

The interference from foreign ions commonly found in water was studied by adding known amounts of foreign species to a solution containing $0.4 \mu \mathrm{g} \mathrm{cm}^{-3}$ of $\mathrm{NO}_{2}^{-}$by this method. Sulphide and $\mathrm{Fe}^{2+}$ can be masked upto 200 and $400 \mu \mathrm{g} \mathrm{cm}^{-3}$ respectively by the additions of $1.0 \mathrm{ml}$ of $1.0 \%$ mercuric chloride and $1.0 \mathrm{ml}$ of $5 \%$ EDTA solution respectively. $\mathrm{Fe}^{3+}$ can be removed as hydroxide with $1.0 \mathrm{ml}$ of $5 \mathrm{~mol} \mathrm{dm}^{-3}$ and tolerated up to $50 \mu \mathrm{g} \mathrm{cm}^{-3}$. The tolerance limits of ions are given in the Table 1 . 
Table 1. Effect of Diverse Species on the Determination of Nitrite $\left(0.4-\mu \mathrm{G} \mathrm{Ml}{ }^{-1}\right)$.

\begin{tabular}{|c|c|}
\hline Foreign ions & $\begin{array}{l}\text { Tolerance limit } \\
\left(\mu \mathrm{g} \mathrm{ml}^{-1}\right)\end{array}$ \\
\hline EDTA & 60000 \\
\hline $\mathrm{NO}_{3}^{-}, \mathrm{Al}^{3+}, \mathrm{Na}^{+}, \mathrm{Ca}^{2+}, \mathrm{CO}_{3}^{2-}$ & 5000 \\
\hline $\begin{array}{l}\mathrm{SO}_{4}^{2-}, \mathrm{Ba}^{2+}, \mathrm{F}^{-} \mathrm{Hg}^{2+}, \mathrm{Mg}^{2+}, \mathrm{Cl}^{-} \\
\text {Tartarate, } \mathrm{PO}_{4}^{3-}\end{array}$ & 4000 \\
\hline $\mathrm{Cd}^{2+}, \mathrm{K}^{+}$ & 2000 \\
\hline $\mathrm{SO}_{3}^{2-}, \mathrm{CH}_{3} \mathrm{COO}^{-}, \mathrm{SCN}^{-}, \mathrm{Pb}^{2+}$ & 1500 \\
\hline $\mathrm{Cu}^{2+}, \mathrm{Fe}^{3+}, \mathrm{V}^{5+}, \mathrm{Ni}^{2+}, \mathrm{Fe}^{2+}$ & $1000^{\mathrm{a}}$ \\
\hline $\mathrm{Mn}^{2+}, \mathrm{I}^{-}, \mathrm{MoO}_{4}^{2-}, \mathrm{Co}^{2+}, \mathrm{Zn}^{2+}, \mathrm{Sn}^{2+}, \mathrm{CN}^{-}$ & 500 \\
\hline${ }^{\mathrm{b}} \mathrm{S}^{2-}$ & 400 \\
\hline $\mathrm{Ag}^{+}, \mathrm{WO}_{4}{ }^{2-}$ & 100 \\
\hline
\end{tabular}

\section{Applications}

Analysis of Industrial Effluent.

Samples are collected in wide-mouthed plastic vessel at different points upstream and downstream from the source of industrial effluents. Samples of potable water were collected from different tanks and different points from lake water. Mercuric chloride (4 mg per 100 $\mathrm{ml}$ of sample) was used for preservation and samples were frozen at $0^{0} \mathrm{C}$ within $1 \mathrm{hr}$ of sampling. Samples were filtered through a Whatman No. 41 paper before analysis.

Two sets of experiments were performed to check the validity of the method. In the first set, the volume of test solution was varied and the absorbance was plotted Vs volume taken. For all the samples linear plots were obtained, which could be extrapolated to the same point as that obtained for demineralised water; this indicates that the determination was quantitative.

In the second set, recovery of $\mathrm{NO}_{2}^{-}$was checked by adding various amounts of $\mathrm{NO}_{2}^{-}$to a fixed volume of test solution. Recoveries were between 100-100.6\%. The results are given in Table 2.

Table 2. Determination of Nitrite in Polluted Water and Tap Water.

\begin{tabular}{cccccc}
\hline \multirow{2}{*}{ Sample } & \multicolumn{3}{c}{ Proposed method } & \multicolumn{2}{c}{ Reported method $^{31}$} \\
\cline { 2 - 6 } & $\begin{array}{c}\text { Nitrite } \\
\text { added } \\
(\mu \mathrm{g})\end{array}$ & $\begin{array}{c}\text { Nitrite } \\
\text { found } \\
(\mu \mathrm{g})\end{array}$ & $\begin{array}{c}\text { Mean } \\
\text { recovery } \\
(\%)\end{array}$ & $\begin{array}{c}\text { Nitrite } \\
\text { found } \\
(\mu \mathrm{g})\end{array}$ & $\begin{array}{c}\text { Mean } \\
\text { recovery } \\
(\%)\end{array}$ \\
\hline Kukarally Lake $^{\mathrm{a}}$ & - & 0.1 & - & $\begin{array}{c}\text { Not } \\
\text { found }\end{array}$ & - \\
Industrial Effluent & - & 3.0 & - & 2.99 & \\
& 0.4 & 0.4 & 100 & 0.4 & 100 \\
Tap Water & 1.8 & 1.79 & 99.4 & 1.81 & 100.5 \\
& 3.0 & 3.02 & 100.6 & 3.01 & 100.6 \\
\hline
\end{tabular}

${ }^{\mathrm{a}}$ Eutrophic Lake, ${ }^{\mathrm{b}}$ Tap water gave no test for nitrite. 
Table 3. Comparison of Spectrophotometric Determination of $\mathrm{NO}^{-}{ }_{2}$ with Other Methods.

\begin{tabular}{|c|c|c|c|c|c|}
\hline Reagent & $\begin{array}{l}\lambda_{\max } \\
(\mathrm{nm})\end{array}$ & $\begin{array}{l}\text { Beer's law } \\
\text { validity } \\
\text { range, } \\
\mu \mathrm{g} \mathrm{ml}^{-1}\end{array}$ & $\begin{array}{c}\text { Molar } \\
\text { absorptivity } \\
1 \mathrm{~mol}^{-1} \mathrm{~cm}^{-1}\end{array}$ & Remarks & Ref. \\
\hline $\begin{array}{l}p-\text { Aminoacetophenone }+ \\
\text { N- (1-Naphthyl) ethylene diamine }\end{array}$ & 545 & $0.1-0.8$ & $4.6 \times 10^{4}$ & $\begin{array}{l}\mathrm{Cu}^{2+}, \mathrm{Fe}^{3+}, \mathrm{S}^{2-} \text {, and } \\
\mathrm{SO}_{2} \text { interfered } \\
\text { seriously }\end{array}$ & 22 \\
\hline $\begin{array}{l}p-\text { Aminobenziocacid }+ \\
\text { N-(1-Naphthyl) ethylenediamine }\end{array}$ & 550 & $0.05-1.2$ & $2.74 \times 10^{4}$ & $\begin{array}{l}\mathrm{Fe}^{2+} \text { and } \mathrm{Fe}^{3+} \\
\text { interfered and less } \\
\text { sensitive than the } \\
\text { proposed method }\end{array}$ & 23 \\
\hline$p$ - rosaniline + phloroglucinol & 420 & $0.04-0.48$ & Not reported & $\begin{array}{l}\mathrm{Cu}^{2+}, \mathrm{Mn}^{2+}, \mathrm{Pb}^{2+}, \mathrm{Fe}^{3+}, \\
\mathrm{Cr}^{6+}, \mathrm{V}^{5+}, \mathrm{SO}_{3}^{2-} \text {, and } \\
\mathrm{S}^{2-} \text { interfered }\end{array}$ & 24 \\
\hline $\begin{array}{l}p \text { - nitroaniline }+ \\
2-\text { methyl }-8-\text { quinolinol }\end{array}$ & 585 & - & $4.72 \times 10^{4}$ & $\begin{array}{l}\text { Most cations and } \\
\text { anions interfered }\end{array}$ & 25 \\
\hline Sulbutamol sulphate & 410 & $1.84-27.6$ & $1.8 \times 10^{3}$ & $\begin{array}{l}\text { Heating required at } \\
100^{\circ} \mathrm{C} \text {, narrow range } \\
\text { of detection }\end{array}$ & 26 \\
\hline 5,7-dihydroxy-4-imino-2- oxychroman & 361 & $0.1-5.0$ & $9.2 \times 10^{3}$ & $\begin{array}{l}\text { Tedious extraction } \\
\text { into butanol-ethyl } \\
\text { acetate }\end{array}$ & 27 \\
\hline Dapsone + phloroglucinol & 425 & $0.008-1.0$ & $4.28 \times 10^{4}$ & - & 28 \\
\hline Dapsone $+\alpha-$ naphthol & 540 & $0.05-0.8$ & $5.749 \times 10^{4}$ & $\begin{array}{l}\text { Simple, rapid and less } \\
\text { detection limit }\end{array}$ & $\begin{array}{l}\text { Present } \\
\text { method }\end{array}$ \\
\hline
\end{tabular}




\section{Conclusion}

The proposed method is economical, fairly selective and precise. The method is more sensitive than some of the reported spectrophotometric methods. In this method, the maximum colour developments take place at ambient temperature and there is no need of heating. The azo dye of the reaction product is stable for a sufficient interval of time, which makes the method more practicable. The low values of relative standard deviation and percentage error indicate the high accuracy of the method and the method freedom from interference by a large group of foreign ions are advantages of this method. Therefore the method can be conveniently used for routine analysis of water and industrial effluent analysis.

\section{Acknowledgements}

One of the authors (JSP) thanks the University of Mysore for providing the laboratory facilities.

\section{References}

1. Patty F A, "Industrial Hygiene and Toxicology", Interscience, New York, 1963, Vol. II.

2. Kolthaff I M, Elving P J and Stross F H, "Treatise on Analytical Chemistry”, Wiley Inter Science, New York, Vo1. 2. Pt. III.

3. McKee J E and Wolf H W, "Water Quality Criteria", Resources Agency of California, State Water Quality Control Board, Publication, 1963, No. 3A, , p.224.

4. Abbasi S A, "Water Quality Sampling and Analysis", (Discovery Publishing House, New Delhi) 1988, pp.191.

5. Garcide C, Mar C. Chem., 1982, 11,159-167.

6. Zhou J Y, Prognon P, Daulphin C and Homan M, HPLC Flurocent Chromatogr., 1993, 36,57-60.

7. Princeton N J, Princeton Applied Research, Application Brief N-1, 1974

8. Wada E and Hattori A, Anal. Chim. Acta, 1971, 56,233-240.

9. Kage S, Kudo K, and Ikeda N, J. Anal. Toxicol., 2002, 26,320.

10. Manzoori J L, Sorouraddin M H and Shabani A M, Talanta, 1998, 46, 1379-1386.

11. Zhang Z Q, Gao L J, Zhan H Y and Lice Q G, Anal. Chim. Acta., 1998, 370, 59-63.

12. Zhang Z Q, Gao L J and Zhan H Y, Talanta, 1998, 47,497-501.

13. Liang B, Iwatsuki M and Fukasawa T, Analyst, 1994,119, 2113 - 2117.

14. Griess P, Chem. Ber., 1879,12,427-428.

15. Chimnescu C and Dorneanu V, Talanta, 1972,19,1474 - 1476.

16. Cai Y and Hu Z, Huaxue-Shiji, 1989,11,73-74

17. Baveja A K and Gupta V K, Chem. Anal., 1983,28,693-699.

18. Garcia E E, Anal. Chem., 1967, 39,1605 - 1607

19. Qian-Feng Wu and Peng - Fei Liu, Talanta, 1983,39,374-376.

20. Kolthaff I M, Stenger V A, Belchar R and Matsuyama G, Volumetric Analysis, 1957, Vol III, pp.69-70, Interscience, New York,.

21. West P W, J. Chem, E.duc., 1941, 18,528.

22. Kaur P, Sunitha S and Gupta V K, J. Indian, 1987; Chem. Soc., 64,428-430.

23. Nagaraja P, Hemantha Kumar M S, Rangappa K S and Suresh A S, Asian J. Chem., 1999,11,509-514.

24. Raman V and Dabbas M S, Micro Chem. J., 1989,40,242. 
25. Fu-pao Isao and Underwood A L, Anal. Chim, Acta, 1982,136,129.

26. Agarwal Y K and Bhatt P N, Anal. Lett., 1988,21,2323.

27. Nakamura M, Mazuka T and Yamashita M, Anal. Chem., 1984,56,2242.

28. Nagaraja P, Hemantha Kumar M S, Yathirajan H S, Annali di chimca (Italy), 2002 92,127-134. 


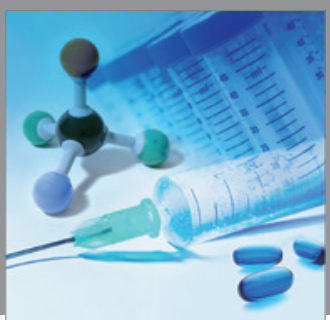

International Journal of

Medicinal Chemistry

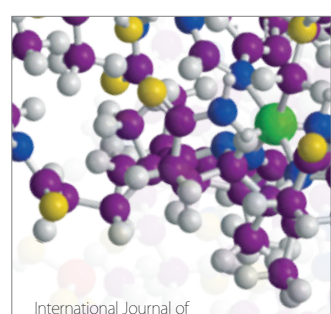

Carbohydrate Chemistry

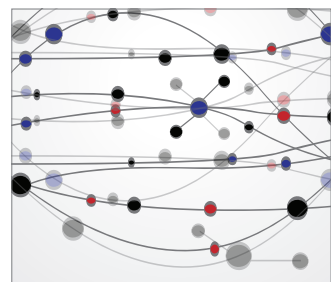

The Scientific World Journal
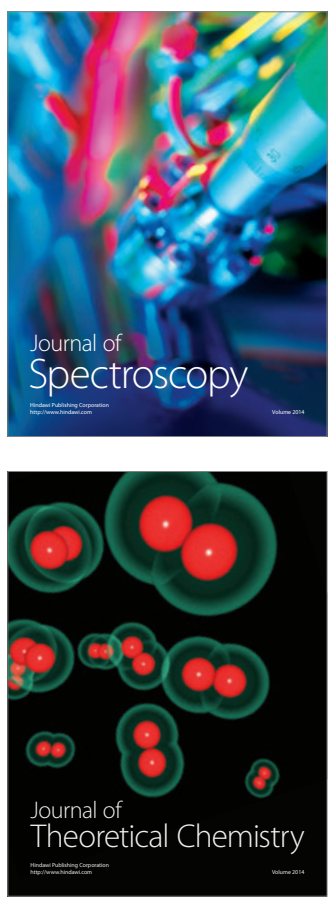
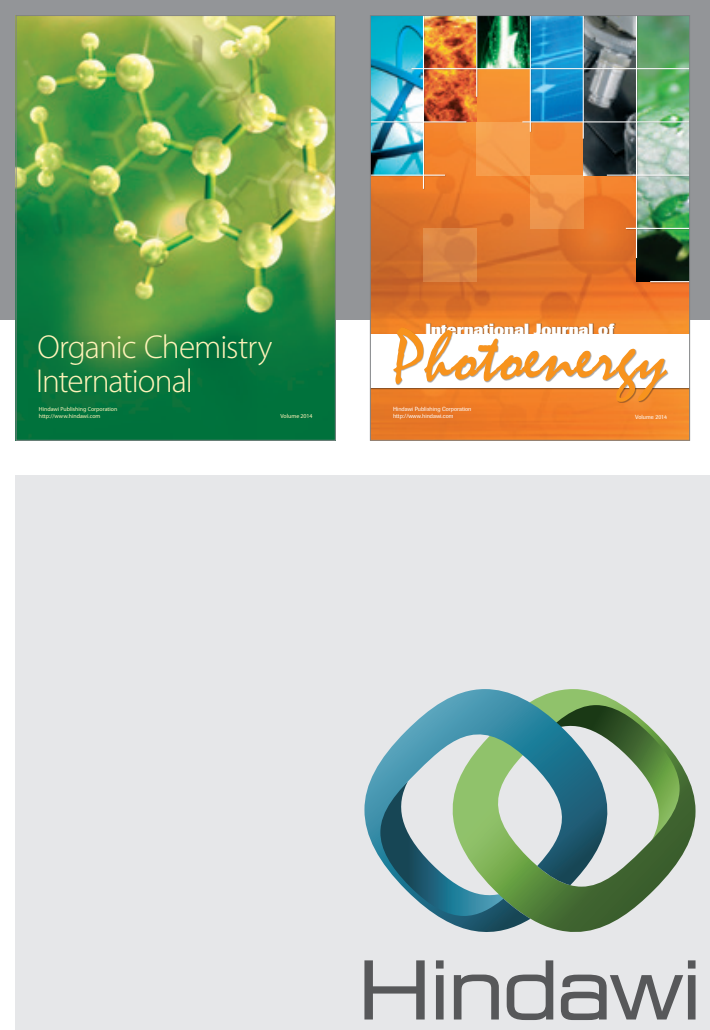

Submit your manuscripts at

http://www.hindawi.com
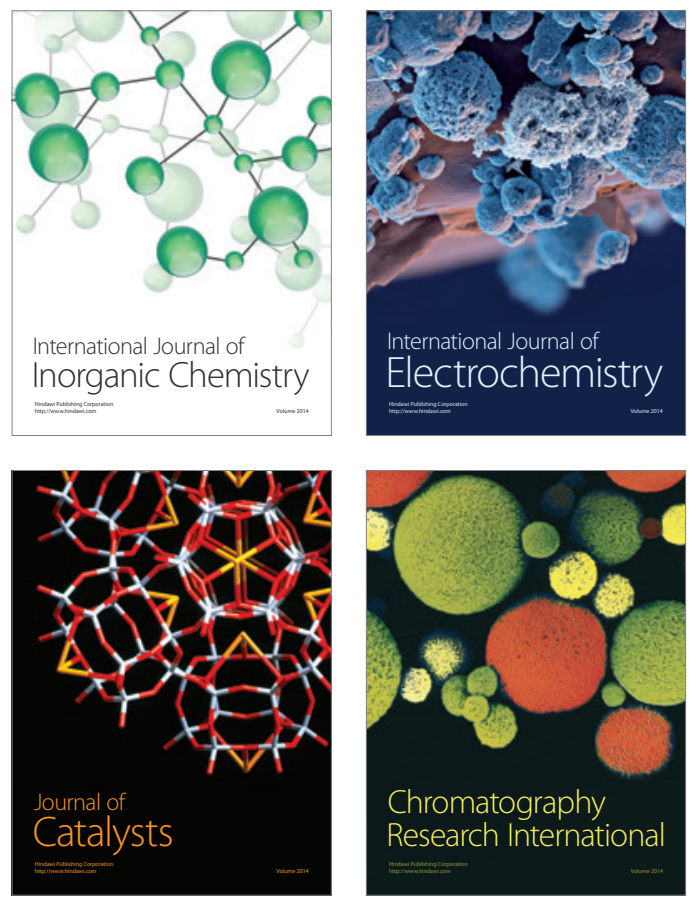
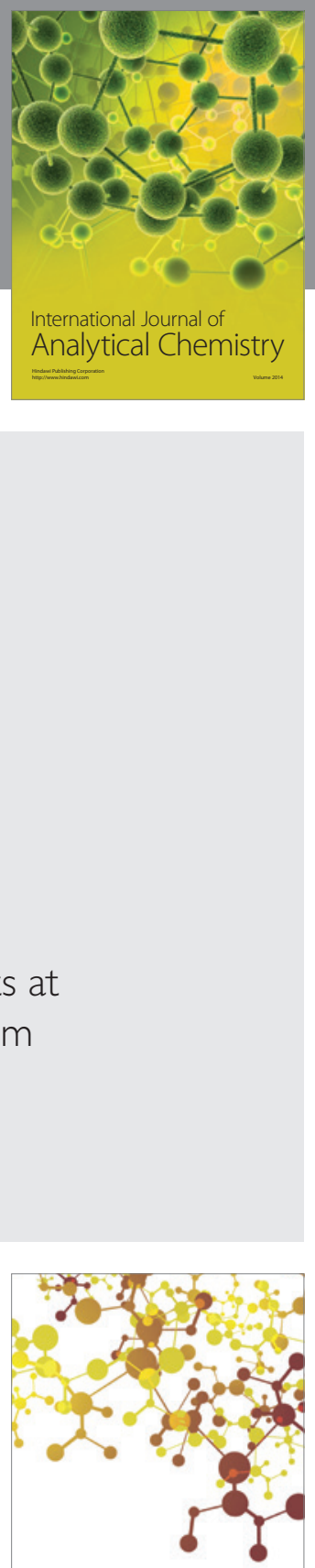

Journal of

Applied Chemistry
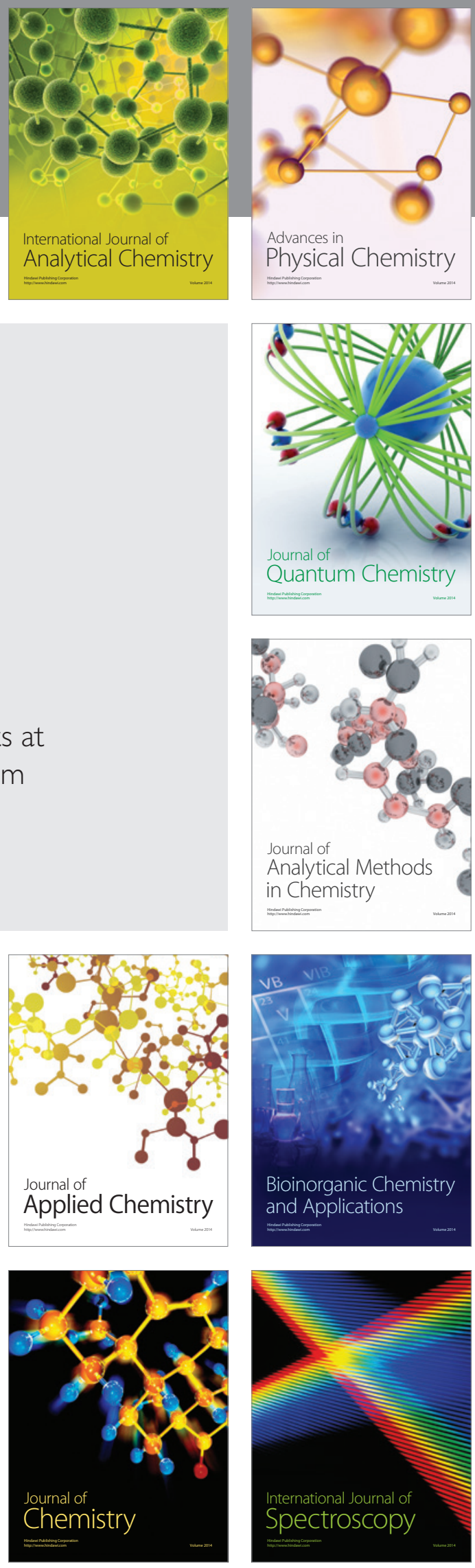